\title{
Kansas Allows Strict Liability Claims Against Used-Product Sellers in Gaumer v. Rossville Truck \& Tractor Co.: Why the Third Restatement Is a Better Approach ${ }^{*}$
}

\section{INTRODUCTION}

In modern products liability law, the doctrine of strict liability in tort is generally considered the principal theory of recovery for consumers who are injured by defective products. ${ }^{1}$ Under strict liability, a party is responsible for injuries caused by defective products that have been sold to consumers. ${ }^{2}$ The traditional rule is that strict liability applies only to defects in new products, but not used products. ${ }^{3}$ For more than four decades, courts have been divided over whether strict liability should apply to sellers of used goods. ${ }^{4}$

The Kansas Supreme Court recently held in Gaumer v. Rossville Truck \& Tractor Co. that Kansas law permits a strict liability action against the seller of a used product. ${ }^{5}$ This decision is misguided. Subjecting used-product sellers to strict liability claims under all circumstances is inappropriate because the policy considerations that have traditionally supported strict liability do not similarly support imposing strict liability on secondhand dealers and used-product sellers. Instead, the Gaumer court should have followed section 8 of the Restatement (Third) of Torts: Products Liability, which provides a better approach for determining when to allow strict liability claims against

* Rachel E. Nelson. J.D. candidate 2013, University of Kansas School of Law; B.A., B.S. 2010, University of Kansas. The Author would like to thank her family and friends for their support, the University of Kansas Law Review Staff and Board for all their hard work, and Professor William E. Westerbeke for his valuable comments.

1. David G. OWEn, Products Liability LaW § 5.1 (2005).

2. Paul Sherman, Products Liability For the General Practitioner § 7.10 (1981).

3. See discussion infra Part II.D.1-2.

4. See Tracy A. Bateman, Annotation, Products Liability: Application of Strict Liability Doctrine to Seller of Used Product, 9 A.L.R.5th 1 (1993 \& Supp. 2010) (collecting cases and noting the divergent views of courts nationally). Compare Turner v. Int'l Harvester Co., 336 A.2d 62 (N.J. Super. Ct. Law Div. 1975) (subjecting used-product seller to strict liability), with Tillman v. Vance Equip. Co., 596 P.2d 1299 (Or. 1979) (declining to subject a used-product seller to strict liability).

5. Gaumer v. Rossville Truck \& Tractor Co., 257 P.3d 292, 308 (Kan. 2011). 
used-product sellers. In Gaumer, the Kansas Supreme Court failed to consider the Third Restatement approach.

This Comment explains that the Third Restatement is a better approach for courts to follow because it provides a compromise in determining when to subject used-product sellers to strict liability. Additionally, it explains why the policy justifications that have conventionally supported imposing strict liability on all parties in the chain of distribution do not similarly support imposing strict liability on used-product sellers in all circumstances.

This Comment begins by outlining the development of the doctrine of strict liability in tort $^{6}$ and the policy considerations that have traditionally supported the doctrine. ${ }^{7}$ Next, it describes how courts originally addressed strict liability and used-product sellers, and it outlines the current split among courts, ${ }^{8}$ including the Kansas Supreme Court's decision in Gaumer that allows strict liability claims against used-product sellers. ${ }^{9}$

Part III examines the court's reasoning in Gaumer and proposes that courts follow the Third Restatement in determining when to impose strict liability on used-product sellers. ${ }^{10}$ It further explains why the policy justifications that support strict liability do not similarly support strict liability for used-product sellers. ${ }^{11}$ This Comment concludes that strict liability is inappropriate for used-product sellers under all circumstances and argues that the Third Restatement, which provides a theory of limited strict liability for secondhand sellers, is the appropriate solution to this increasingly prevalent products liability concern. ${ }^{12}$

\section{BACKGROUND}

Products liability law is a mixture of tort law and contract law. ${ }^{13}$ The elements derived from tort law-negligence, strict liability, and deceitdeveloped primarily based on common law. ${ }^{14}$ The elements borrowed

6. See discussion infra Part II.B.

7. See discussion infra Part II.C.

8. See discussion infra Part II.D.1-2.

9. See discussion infra Part II.D.3.

10. See discussion infra Parts III.A-B.

11. See discussion infra Part III.C.

12. See discussion infra Part III.A-C.

13. David G. OWen, Products Liability LaW IN A Nut Shell $\S 1.1$ (8th ed. 2008).

14. Id. 
from contract law developed largely through common law warranties as codified under the Uniform Commercial Code. ${ }^{15}$ Because of the interrelatedness of these separate areas of law that encompass products liability law, "plaintiffs often have a variety of available claims" when a product injures a consumer. ${ }^{16}$ This section will begin by explaining the early obstacles that consumers faced in recovering under a products liability claim. ${ }^{17}$ It will then discuss how strict liability developed in the United States, including the adoption of section 402 of the Second Restatement and section 8 of the Third Restatement. ${ }^{18}$ This section concludes by examining the public policies that support strict liability ${ }^{19}$ and the current jurisdictional split on when to impose strict liability on secondhand or used-product sellers. ${ }^{20}$

\section{A. The Early Obstacles to Recovery Under Products Liability Law}

Prior to the adoption of section 402A of the Restatement (Second) of Torts (Second Restatement), injured consumers had "bleak prospects for recovery." 21 For defective products, a plaintiff could rely on negligence or breach of implied warranty theories. ${ }^{22}$ For misrepresentation of a product's condition or quality, a plaintiff could file an action for fraud, negligent representation, or breach of express warranty. ${ }^{23}$ But all theories posed serious obstacles to recovery because of "the privity requirement, undue burdens in proving negligence, and other contract barriers such as notice, disclaimer, and limitations of remedy." ${ }^{24}$

Initially, courts required plaintiffs to show privity of contract with the manufacturer. ${ }^{25}$ Even though this requirement eroded in negligence actions after the seminal case MacPherson v. Buick Motor Co., ${ }^{26}$ most plaintiffs still struggled to prove negligence from an evidentiary

15. Id.

16. Id.

17. See discussion infra Part II.A.

18. See discussion infra Part II.B.

19. See discussion infra Part II.C.

20. See discussion infra Part II.D.

21. William E. Westerbeke, The Sources of Controversy in the New Restatement of Products Liability: Strict Liability Versus Products Liability, KAN. J. L. \& PUB. POL’Y, Fall 1998, at 1.

22. Id.

23. Id.

24. Id. at 2 .

25. Id.

26. Id. at 2 n.6 (citing MacPherson v. Buick Motor Co., 111 N.E. 1050 (N.Y. 1916)). 
standpoint. $^{27}$ To win a negligence claim, for example, a plaintiff must prove fault on the part of the manufacturer. Specifically, a plaintiff must prove that a manufacturer acted in an unreasonable manner during the manufacturing process, thus creating a defective product. Then a plaintiff must prove that the defect was the actual and proximate cause of plaintiff's injuries or damages. This was difficult to prove because there was not likely any direct evidence of negligence in the manufacturing process. $^{28}$ Further, the increasingly modern and complex methods of manufacturing and distribution that involve multiple producers only exacerbated a plaintiff's burden. ${ }^{29}$ Even if the evidence were available, a plaintiff often may not be able to access it or afford the litigation costs. ${ }^{30}$

MacPherson v. Buick Motor Co.- - the same case that abolished the privity requirement for negligence claims-greatly restricted the privity requirement for warranty actions. ${ }^{31}$ Previously, courts required a plaintiff to establish privity of contract between the plaintiff and the manufacturer or seller. ${ }^{32}$ This essentially meant that if a person had not purchased the product directly from the manufacturer, then he could not sue the manufacturer and had no possible cause of action. ${ }^{33}$ This made it particularly difficult for consumers when manufacturers began distributing their products to users "through networks of independent wholesalers and retailers." ${ }^{34}$ Following MacPherson, however, courts began to recognize a consumer's right to sue a "remote" manufacturer for negligence ${ }^{35}$ because a negligence claim depended on the "foreseeability of risk, not on a contractual relationship between the

\section{Id. at 3 .}

28. Id.

29. See id. (describing the difficulty of proving where a defect occurred when multiple companies and stages of manufacture are involved).

30. See id. (explaining that the "plaintiff often lived far from the place of manufacture" and that "[t]he plaintiff's lawyer was more likely than not a sole practitioner with limited resources to pursue a distant manufacturer").

31. 111 N.E. 1050. The implied warranty of merchantability is the warranty that is based on defectiveness, U.C.C. § 2-314 (1977), and parallels negligence and strict liability. Express warranties parallel misrepresentation and section 402 of the Second Restatement. Warranty obstacles include privity under U.C.C. § 2-318, notice under U.C.C. § 2-607(3)(a), disclaimer of warranty protection under U.C.C. § 2-316, limitation of the available remedies under U.C.C. § 2719, and a statute of limitations running from the date of sale with no discovery rule.

32. Westerbeke, supra note 21, at 2.

33. Id.

34. Id.

35. Id. The MacPherson rule was almost universally adopted throughout the United States. See Carter v. Yardley \& Co., 64 N.E.2d 693, 700 (Mass. 1946). 
parties.”36 Therefore, courts eventually recognized a consumer's right to sue a remote manufacturer under breach of warranty when the product, "if defectively made, would be unreasonably dangerous to users or consumers of the product." ${ }^{\text {} 37}$ In response, manufacturers started finding ways to get around the warranty through disclaimers and limitations of remedies. ${ }^{38}$

A possible solution to privity and proof obstacles was an action for breach of implied warranty of merchantability under contract law. ${ }^{39}$ Under an implied warranty of merchantability theory, "the issue was not whether the defective condition resulted from the seller's negligence, but simply whether the defective condition rendered the product unfit for its ordinary purposes." ${ }^{40}$ Liability was strict because fault was completely irrelevant to a breach of implied warranty claim. ${ }^{41}$ An implied warranty action was still generally unavailable, however, because sellers were protected in most circumstances by a variety of limitations on warranty liability. ${ }^{42}$ The theory of strict liability eventually eliminated these hurdles, in the interest of protecting consumers, by allowing them to recover damages for injuries caused by sellers of defective goods.

\section{B. The Development of Strict Liability in Tort for Product Defects}

Strict products liability in tort did not emerge in U.S. courts until the 1960s. ${ }^{43}$ It arose to alleviate product-safety concerns that stemmed from the modernization of manufacturing and distribution processes. ${ }^{44}$ It also lightened the constraints that traditional products liability claims placed on injured plaintiffs. ${ }^{45}$ The development and expansion of the doctrine

\footnotetext{
36. Westerbeke, supra note 21 , at 2 .

37. Id.

38. Id. at 4.

39. Id.

40. Id.

41. Id.

42. Id.

43. OWEN, supra note 1 , § 5.1 .
}

44. See, e.g., Escola v. Coca Cola Bottling Co. of Fresno, 150 P.2d 436, 440 (Cal. 1944) (Traynor, J., concurring) (en banc) (explaining that "public policy demands that responsibility be fixed wherever it will most effectively reduce the hazards to life and health inherent in defective products that reach the market”).

45. See supra Part II.A. 
of strict liability in tort became the "centerpiece around which the rest of modern products liability law was formed."46

1. Recognizing the Doctrine of Strict Products Liability in Tort

The doctrine of strict products liability was first recognized and applied in 1963 in Greenman v. Yuba Power Products, Inc. ${ }^{47}$ In this landmark case, the California Supreme Court held that "[a] manufacturer is strictly liable in tort when an article he places on the market, knowing that it is to be used without inspection for defects, proves to have a defect that causes injury to a human being." 48 Justice Traynor explained that product liability claims should not be governed by the law of contract warranties but by the law of strict liability in tort. ${ }^{49}$ The rules that define and govern warranties were "developed to meet the needs of commercial transactions [and] cannot properly be invoked to govern the manufacturer's liability to those injured by their defective products unless those rules also serve the purposes for which such liability is imposed."50 Strict liability, the court opined, protects injured consumers by forcing manufacturers to cover the costs of injuries that result from defective products that they put on the market because consumers are "powerless to protect themselves" from these injuries. ${ }^{51}$

The California Supreme Court had laid the foundation for Greenman with its 1944 opinion in Escola v. Coca Cola Bottling Co. of Fresno. ${ }^{52}$ In Escola, Justice Traynor opined that public policy demands that manufacturers, who can "most effectively reduce the hazards to life and health inherent in defective products," should bear the responsibility of compensating those who suffer injury from defective products. ${ }^{53}$ The year following Greenman, the California Supreme Court, in Vandermark v. Ford Motor Co., further extended strict liability from manufacturers to all parties involved in the manufacturing, distribution, and sale of defective products, including retailers. ${ }^{54}$ Justice Traynor explained that

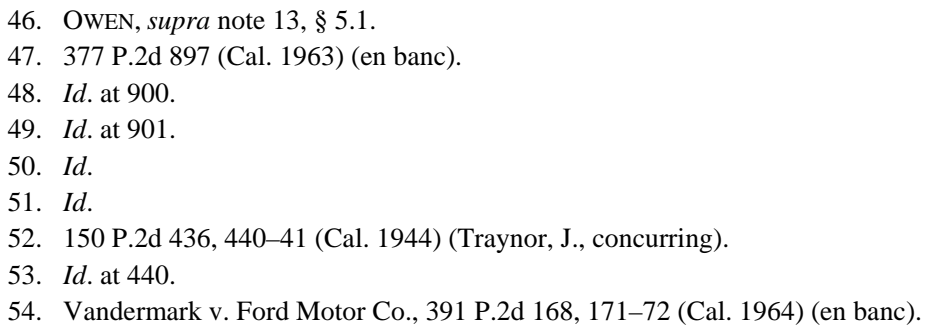


retailers, just like manufacturers, engage in distributing goods to the public and therefore play an "integral" role in the producing and marketing enterprise. ${ }^{55}$ He explained that they should "bear the cost of injuries" that might result from defective products because they might quite possibly be the only party that an injured plaintiff can hold liable for his injuries. ${ }^{56}$

\section{Defining “Strict” Liability}

Strict liability rests on the policy that a manufacturer or seller should bear responsibility for a consumer's losses or injuries that the manufacturer or seller caused. ${ }^{57}$ It does not consider the defendant's behavior but, rather, evaluates the "nature of the allegedly defective product." " It is "strict" because it applies even though a seller has exercised all possible reasonable care in preparing the sale of a product, thus allowing a consumer to receive compensation for injuries caused by a defective product regardless of the defendant's fault. ${ }^{59}$

Strict liability, as originally outlined in section 402A of the Second Restatement, applied to manufacturing, design, and warning defects. ${ }^{60}$ It also used the consumer-expectations test for defectiveness. ${ }^{61}$ This test paralleled the concept underlying the implied warranty of merchantability, which essentially protects consumers against hidden dangers. ${ }^{62}$ Section 2 of the Third Restatement, however, reformulated the doctrine of strict liability. ${ }^{63}$ The Third Restatement supersedes section 402A and allows strict liability only for claims of manufacturing defects by using what is in essence a negligence test for design and

\footnotetext{
55. Id. at 171.

56. Id.

57. See Frank J. VANDALl, StRict Liability: Legal And ECONOMiC ANALYSis 43 (1989).

58. Karl A. Boedecker \& Fred W. Morgan, Strict Liability for Sellers of Used Products: A Conceptual Rationale and Current Status, 12 J. PUB. POL'Y \& MARKETING 178, 179 (1993).

59. OWEN, supra note 1 , § 5.3; see also RESTATEMENT (SECOND) OF TORTS § 402A \& cmts. a, c (1965).

60. See discussion infra Part II.B.3.

61. Restatement (SECOND) OF TORTS § 402A \& cmt. i (1965); see also infra notes 179-81 and accompanying text.

62. The implied warranty of merchantability, outlined in U.C.C. § 2-314 (1977), recognizes some limited warranty protection for buyers of used goods. The buyer and seller, however, may allocate risks in the transaction using disclaimers or limitations of remedy. See U.C.C. §§ 2-316, 2317.

63. Restatement (Third) OF ToRTS: Prods. Liab. § 2 (1998).
} 
warning defects. ${ }^{64}$ Under this new framework, there are four main situations for which strict liability is the only method to hold a party liable: (1) manufacturing defects where the plaintiff cannot prove fault on the part of the party that caused the defect; (2) design defects where the danger exists and is known, but the product provides benefits and there is no known alternative design that would eliminate or reduce the danger involved with the first product; ${ }^{65}$ (3) design defects with unforeseeable, scientifically undiscoverable dangers; and (4) warning defects with unforeseeable, scientifically undiscoverable dangers. For all of these situations, a reasonable manufacturer or seller could not have used any more care, so liability was truly "strict."

\section{Adopting Section 402A of the Restatement (Second) of Torts}

In 1965, the American Law Institute (ALI) published the theory of strict liability in section 402A of the Second Restatement. ${ }^{66}$ By the mid1970s, more than forty states had adopted the theory of strict liability for manufacturers in tort for the sale of defective products. ${ }^{67}$ As of 2005, only five states had formally rejected the doctrine of strict liability under section 402A. ${ }^{68}$ Section 402A(1) states:

One who sells any product in a defective condition unreasonably dangerous to the user or consumer or to his property is subject to liability for physical harm thereby caused to the ultimate user or consumer, or to his property, if

(a) the seller is engaged in the business of selling such a product, and

(b) it is expected to and does reach the user or consumer without substantial change in the condition in which it is sold. ${ }^{69}$

The Second Restatement does not distinguish among manufacturing, design, and warning defects-it simply applies to any product with a

64. Id. § 2(a)-(c).

65. This situation is common for problems with prescription drugs, where the drug is unavoidably unsafe but can still justifiably be given because there is no alternative drug available. See Restatement (SECOND) OF TORTS § 402A cmt. k.

66. Id. § 402A.

67. OWEN, supra note 1 , § 5.3 .

68. Id. The five states that have formally rejected the doctrine of strict products liability in tort are Delaware, Massachusetts, Michigan, North Carolina, and Virginia. Id. These states essentially apply many of the principles outlined in section 402A either through the law of warranty or the law of negligence. $I d$.

69. RESTATEMENT (SECOND) OF TORTS § 402A(1). 
defective condition that is "unreasonably dangerous" to the consumer. ${ }^{70}$ Section 402A goes on to state that subsection 1 of the rule applies even if "the seller has exercised all possible care in the preparation and sale of his product." ${ }^{71}$ It thus allows a strict liability claim without proof of fault. The section also allows liability even if the consumer did not buy the product from or enter into a contract with the seller. ${ }^{72}$ This provision abolishes the privity of contract requirement that courts had previously required. ${ }^{73}$ Section $402 \mathrm{~A}$ also states that any seller who is "engaged in the business of selling such a product" can be held strictly liable. ${ }^{74}$ This is commonly referred to as the "chain of distribution" theory. ${ }^{75}$ Any party that participates in the product's chain of distribution-including a manufacturer, wholesaler, retailer, dealer, distributor, or restaurant operator-may face strict liability. ${ }^{76}$ The underlying rationale for section 402A was that a "seller, by marketing his product...., has undertaken and assumed a special responsibility" towards the general public, and he must bear the burden of accidental injuries that might be caused by his products. ${ }^{77}$ The Second Restatement makes no distinction between new and used products, ${ }^{78}$ and the comments to section 402A fail to discuss or mention used products. Since the adoption of this section, products liability law "has moved far beyond the original formulation of the doctrine as described in [section] 402A and its comments."79

4. Adopting Section 8 of the Restatement (Third) of Torts: Products Liability

In 1998, the ALI published section 8 of the Third Restatement ${ }^{80}$ to "organize, clarify and restate thirty years of case law" decided under section 402A of the Second Restatement. ${ }^{81}$ Section 8 largely dismantles

70. See id.

71. Id. § $402 \mathrm{~A}(2)(\mathrm{a})$.

72. Id. § 402A(2)(b).

73. OWEN, supra note 1 , § 5.3 .

74. RESTATEMENT (SECOND) OF TORTS $§$ 402A(1)(a).

75. See, e.g., Seattle-First Nat'l Bank v. Tabert, 542 P.2d 774, 776 (Wash. 1975) (en banc) ("[Strict] liability is extended to those in the chain of distribution.").

76. RESTATEMENT (SECOND) OF TORTS § 402A cmt. f.

77. Id. § $402 \mathrm{~A} \mathrm{cmt.} \mathrm{c.}$

78. See id. § 402A(1)(a) (“One who sells any product ....” (emphasis added)).

79. OWEN, supra note 1 , § 5.3 .

80. Restatement (THIRD) OF TORTS: PRODS. Liab. § 8 (1998).

81. Westerbeke, supra note 21 , at 1. 
section 402A and essentially abandons strict liability for design and warning cases, which comprised much of products liability litigation prior to the adoption of section 402A in $1965 .{ }^{82}$ It therefore governs only manufacturing defects. Section 8 directly addresses used products, subjecting any party who is in the chain of distribution for a used product to liability for a defect that harms a consumer if (a) the defect is a result of "the seller's failure to exercise reasonable care," ${ }^{, 83}$ (b) the seller markets a product with a manufacturing defect in a way that would lead a reasonable buyer to expect that the used product "present[ed] no greater risk of defect than if the product were new," ${ }^{84}$ (c) the defect is a manufacturing defect in a remanufactured product, ${ }^{85}$ or (d) the defect results from a used product's noncompliance with a product safety statute or regulation. ${ }^{86}$

Although the ALI published section 8 to clarify section 402A, most states continue to base their products liability law solely on section 402A. ${ }^{87}$ Section 402A has caused confusion for courts because it does not directly address the issue of whether the doctrine of strict liability should apply to used-product sellers. Because most states have adopted section 402A instead of section 8, courts disagree about how to determine when strict liability should apply to a used-product seller.

\section{Public Policies Supporting the Imposition of Strict Liability}

Courts have relied predominately on four public policies to justify imposing strict liability on product manufacturers and sellers: enterprise liability, deterrence of risks associated with placing defective products into the stream of commerce, implied representation that products are safe for use, and consumer compensation. ${ }^{88}$

82. OWEN, supra note 1 , § 5.1.

83. Restatement (Third) OF TORTS: PRods. Liab. § 8(a).

84. Id. § 8(b).

85. Id. § 8(c).

86. Id. § 8(d).

87. OWEN, supra note $1, \S 1.3$.

88. See, e.g., Antonio J. Senagore, The Benefits of Limiting Strict Liability for Used-Product Sellers, 30 N. ILL. U. L. REV. 349, 356-59 (2010) (discussing enterprise liability and efficient resource allocation, risk deterrence, implied representation and consumer expectation, and fairness and compensation); David B. Goodwin, Note, Protecting the Buyer of Used Products: Is Strict Liability for Commercial Sellers Desirable?, 33 STAN. L. REV. 535, 537-48 (1981) (discussing enterprise liability, market deterrence, compensation, and implied representation as strict liability policy justifications); Derrick Williams, Note, Secondhand Jurisprudence in Need of Legislative Repair: The Application of Strict Liability to Commercial Sellers of Used Goods, 9 TEX. WESLEYAN 


\section{Enterprise Liability}

Many courts have used the concept of enterprise liability as the main justification for imposing strict liability in products liability cases. ${ }^{89}$ The theory, in its most basic sense, is that "losses to society created or caused by an enterprise or ... an activity[] ought to be borne by that enterprise or activity." 90 In other words, the price of a product should include and reflect the costs of possible accidents that might result from defects in that product. ${ }^{91}$ Imposing strict liability on product manufacturers forces them to price their products based on all of their expenses, which include costs of injuries resulting from the product as well as insurance to cover those costs. $^{92}$ Consumers who purchase that product then bear that cost. $^{93}$ This increased price "reflects the justifiable expectations of customers regarding safety, quality[,] and durability of new goods."94

This policy is meant to allocate resources by a product's true cost to society and ultimately result in an "equitable spreading of risk between consumers and sellers." ${ }^{\text {" }}$ This justification works well for manufacturing defects, which may occur only "intermittently." 66 The manufacturer may then spread the costs of that single accident over the production of a large number of units, which only minimally impacts the cost of that product. Although this will lead to a slight increase in product prices, it will eventually force manufacturers to produce fewer dangerous goods because consumers will not buy the goods that cost more. $^{97}$ This theory, however, does not work well to support imposing

L. REV. 255, 269-73 (2003) (same).

89. See, e.g., Jordan v. Sunnyslope Appliance Propane \& Plumbing Supplies Co., 660 P.2d 1236, 1242 (Ariz. Ct. App. 1983) (stating that enterprise liability is a basis for strict liability under Arizona law); Hall v. Armstrong Cork, Inc., 692 P.2d 787, 791 (Wash. 1984) (en banc) (observing that the primary purpose of strict liability is "spreading throughout society the cost of compensating" injured consumers); Nelson v. Nelson Hardware, Inc., 467 N.W.2d 518, 525 (Wis. 1991) (explaining that one policy justification for imposing strict liability is spreading the risk of losses to the manufacturer).

90. Howard C. Klemme, The Enterprise Liability Theory of Torts, 47 U. CoLO. L. REv. 153, 158 (1976) (citing O’Neill v. Leamer, 239 U.S. 244 (1915)).

91. Goodwin, supra note 88, at 537. This is often referred to as "cost internalization."

92. Turner v. Int'l Harvester Co., 336 A.2d 62, 69 (N.J. Super. Ct. Law Div. 1975).

93. Id.

94. Id.

95. Senagore, supra note 88, at 357.

96. See, e.g., Escola v. Coca Cola Bottling Co. of Fresno, 150 P.2d 436, 440-41 (Cal. 1944) (en banc) (Traynor, J., concurring).

97. Senagore, supra note 88 , at 357. 
strict liability for design or warning defects, where generally each unit that was produced will have the same defect. This theory ultimately supports the imposition of strict liability on manufacturers and sellers because it decreases the number of dangerous products that are available to consumers and encourages manufacturers and sellers to place safer products into the stream of commerce.

2. Deterrence of Risks Associated with Placing Defective Products into the Stream of Commerce

A second important policy justification behind strict liability is deterring manufacturers and sellers from placing defective products into the stream of commerce, thereby reducing the number of product-related injuries and the costs associated with them. ${ }^{98}$ The law also achieves this by incorporating the costs of accidents into the costs of manufacturing, which increases product costs and reduces consumer demand for dangerous goods. ${ }^{99}$ Increased potential for liability and higher costs create an economic incentive for manufacturers to make safer products ${ }^{100}$ and, thus, support the imposition of strict liability on manufacturers and sellers. Deterrence is fundamentally a rationale for simple negligence because the law cannot deter someone from causing a risk for something that no one knows exists, as is the case for many product defects.

\section{Implied Representation of Product Safety}

The implied representation justification for strict liability originates from the doctrine of implied warranty of merchantability for products. ${ }^{101}$ This justification rests on the idea that when a manufacturer or seller places a product into the steam of commerce, it implies "that the product will be safe, if used as intended."102 This protects consumers' reasonable expectations of product safety and forces product manufacturers to guarantee the implicit safety of their products. ${ }^{103}$ Implied representation supports imposing strict liability on product manufacturers because they

98. William L. Humes, Note, The Application of Strict Liability in Tort to the Retailers of Used Products: A Proposal, 16 OKLA. CITY U. L. ReV. 373, 393 (1991).

99. Senagore, supra note 88 , at 358.

100. Id.

101. Goodwin, supra note 88, at 544

102. Humes, supra note 98 , at 395.

103. Williams, supra note 88 , at 272-73. 
have the ability to ensure that they produce safe products.

\section{Consumer Compensation}

Another policy justification behind strict liability is compensating injured parties. Strict liability does not require the injured party to prove the manufacturer's fault to win on a strict liability claim, making it easier for consumers to win compensation for injuries sustained from defective products. ${ }^{104}$ Requiring the manufacturer to insure against accidents caused by product defects can force all potential buyers to bear those costs instead of placing the burden on an individual accident victim. This policy alone would not support imposing strict liability, but as a matter of fairness to consumers, it is still a justification for strict liability. ${ }^{105}$

\section{Strict Liability for Used-Product Sellers: Courts Divided}

The current split concerning strict liability and used-product sellers results from different interpretations of section 402A. ${ }^{106}$ Section 402A does not directly address the issue of strict liability for used-product sellers. The commentary that accompanies section 402A, however, has led most courts to agree on at least one point: that strict liability should apply only to sellers who are "in the business of selling products for use or consumption." 107

Courts vary in the specific circumstances under which they have held used-product sellers strictly liable for defective products. ${ }^{108}$ One treatise explained strict liability as a recipe, stating that "every jurisdiction has its own special herbs, spices, and flavorings to differentiate its own version of strict liability from that of its neighbors ... [and] given the dynamics of products liability common law, sometimes the mix of ingredients is changing." " The next two sections examine these divergent views.

\section{Majority View: Used-Product Sellers Are Not Subject to Strict}

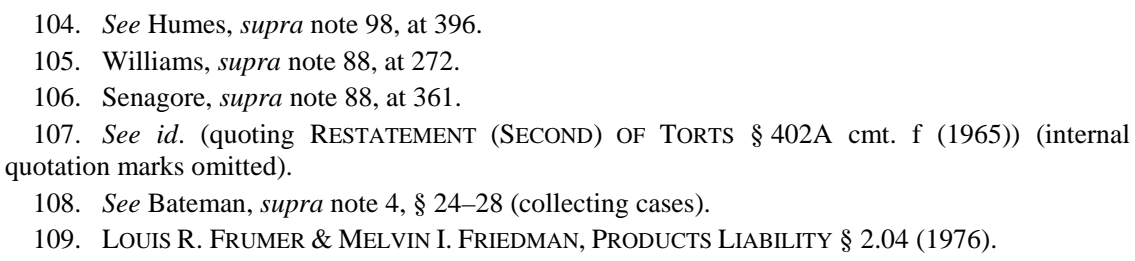


Liability

Most courts that have protected used-product sellers from strict liability for product defects have explained that strict liability is not justifiable unless the seller "repaired or modified the product, caused the defect, or made some representation regarding quality."110 If the product is in the same condition as when the seller acquired it, then most courts will not apply strict liability. ${ }^{111}$ These decisions primarily rely on the fact that the underlying policy justifications for strict liability against product manufacturers do not justify holding used-product sellers strictly liable. ${ }^{112}$

In 1979, the Oregon Supreme Court was one of the first courts to hold that strict liability should not apply to used-product sellers because there are no compelling public policy justifications for extending the doctrine from manufacturers and new-product sellers to used-product sellers. ${ }^{113}$ In Tillman v. Vance Equipment Co., the court explained that extending strict liability to used-product sellers would not achieve the goals of fulfilling consumer expectations of safety or reducing the risks associated with defective products. ${ }^{114}$ With respect to consumer expectations of safety, the court observed that used-product sellers, although in the "business of selling [certain] goods," generally do not make a "particular representation about their quality simply by offering them for sale."115 The court further explained that if a buyer wanted

110. Bateman, supra note 4.

111. See, e.g., King v. Damiron Corp., 113 F.3d 93, 96 (7th Cir. 1997); Harber v. Altec Indus., Inc., 812 F. Supp. 954, 961-65 (W.D. Mo.), aff'd, 5 F.3d 339 (8th Cir. 1993) (per curiam); Keith v. Russell T. Bundy \& Assocs., 495 So. 2d 1223, 1227 (Fla. Dist. Ct. App. 1986); Peterson v. Lou Bachrodt Chevrolet Co., 329 N.E.2d 785, 787 (Ill. 1975); Grimes v. Axtell Ford Lincoln-Mercury, 403 N.W.2d 781, 785 (Iowa 1987); Harrison v. Bill Cairns Pontiac of Marlow Heights, Inc., 549 A.2d 385, 392-93 (Md. Ct. Spec. App. 1988); Gorath v. Rockwell Int'l, Inc., 441 N.W.2d 128, 13132 (Minn. Ct. App. 1989); Jaramillo v. Weyerhaeuser Co., 906 N.E.2d 387, 394 (N.Y. 2009); Allenberg v. Bentley Hedges Travel Serv., Inc., 22 P.3d 223, 225-30 (Okla. 2001); Tillman v. Vance Equip. Co., 596 P.2d 1299, 1303-04 (Or. 1979).

112. Allenberg, 22 P.3d at 229-30; see also Tillman, 596 P.2d at 1304 (finding that "the relevant policy considerations" are inapplicable to used-product sellers when the used-product seller did not make a representation of quality of the product beyond the sale itself or is not in a special position to influence the original manufacturer or others in the "chain of original distribution").

113. Tillman, 596 P.2d at 1304. In Tillman, a defectively manufactured crane injured the plaintiff, who had purchased the twenty-four-year-old crane in "as is" condition from a usedproducts seller. Id. at 1300 . The court held that the used-product seller was not strictly liable in tort for the injuries caused by the crane. Id. at 1304 .

114. Id. at 1304.

115. Id. at 1303. 
assurance that the product was of good quality, he could seek out a newproduct seller or dealer who "routinely" offers such goods rather than a used-goods dealer. ${ }^{116}$ The court concluded that used-product sales alone did not create the same "expectations of safety that courts have held are justifiably created by the introduction of a new product into the stream of commerce."117

In addressing how to reduce the risks often associated with sales of defective products, the Tillman court explained that new-product sellers will usually have some sort of relationship with manufacturers or distributors so that they can communicate safety concerns, whereas usedproduct sellers "generally ha[ve] no direct relationship with either manufacturers or distributors." 118 Thus, the used-product seller does not have a direct "channel of communication" with the manufacturer or distributor to discuss "possible dangerous defects in particular product lines or ... actual and potential liability claims." 119 The court also explained that used-product sellers generally have a difficult time obtaining indemnity for losses because of various statutes of limitations and problems that they often have in trying to locate an original manufacturer or distributor of a used product. ${ }^{120}$ The Oregon Supreme Court opined that this prevents used-product sellers, as contrasted with new-product sellers, from exerting the requisite financial pressure on manufacturers to encourage production of safer goods. ${ }^{121}$

The rationale in Tillman persuaded many courts. By 2001, at least four state supreme courts had followed Tillman explicitly and rejected plaintiffs' attempts to impose strict liability on used-product sellers. ${ }^{122}$ The California Courts of Appeal issued numerous decisions that relied on the same policy rationales as Tillman. ${ }^{123}$ In 2001, the Oklahoma Supreme Court held that strict liability did not apply to the commercial

116. Id.

117. Id. at 1304

118. Id.

119. Id.

120. Id.

121. Id.

122. See Peterson v. Superior Court, 899 P.2d 905, 915 (Cal. 1995) (en banc); Peterson v. Idaho First Nat'l Bank, 791 P.2d 1303, 1304-06 (Idaho 1990); Grimes v. Axtell Ford Lincoln-Mercury, 403 N.W.2d 781, 784-85 (Iowa 1987); Allenberg v. Bentley Hedges Travel Serv., Inc., 22 P.3d 223, 229-30 (Okla. 2001).

123. See, e.g., Tauber-Arons Auctioneers Co. v. Superior Court, 161 Cal. Rptr. 789, $796-98$ (Ct. App. 1980) (finding that policy considerations do not support imposing strict liability on usedproduct sellers); see also LaRosa v. Superior Court, 176 Cal. Rptr. 224, 231 (Ct. App. 1981) (noting that "Tauber-Aron's reasoning is sound"). 
seller of a used product who did not create the defect and who sold the product in basically the same condition as when it acquired the product for resale. ${ }^{124}$ It reasoned that the policy justifications that motivate strict liability are "not fully applicable to commercial sellers of used products" ${ }^{\text {"125 }}$ because used-product sellers, unlike manufacturers, are not the best party to protect against the risk of being injured by a defective product. $^{126}$ The Third Restatement also adopts the majority rule, providing that a used-product seller is only liable under the circumstances set out in the Restatement. ${ }^{127}$

\section{Minority View: Used-Product Sellers Are Subject to Strictly Liability}

Some courts have found that used-product sellers are essentially the same as new-product sellers and should be held to the same standards as new-product sellers. ${ }^{128}$ One of the earliest cases finding that strict liability could be imposed on a used-product seller was Turner $v$. International Harvester Co. in 1975. ${ }^{129}$ The New Jersey Superior Court explained that a secondhand seller is strictly liable for injury caused by an unreasonably dangerous condition of a product because of a safety defect that was present in the vehicle when it was in the dealer's control. ${ }^{130}$ It further observed that holding used-product sellers strictly liable would spread costs of possible damages and insurance to cover the damages among all consumers the same way that strict liability does for

\footnotetext{
124. Allenberg, 22 P.3d at 225-26.

125. Id. at 229-30.

126. Id. at 230-31.

127. See supra Part II.B.4.

128. See, e.g., Galindo v. Precision Am. Corp., 754 F.2d 1212, 1218-21 (5th Cir. 1985); Gonzales v. Rutherford Corp., 881 F. Supp. 829, 841-44 (E.D.N.Y. 1995); Stillie v. AM Int'l, Inc., 850 F. Supp. 960, 961-63 (D. Kan. 1994); Jordan v. Sunnyslope Appliance Propane \& Plumbing Supplies Co., 660 P.2d 1236, 1241-42 (Ariz. Ct. App. 1983); Stanton v. Carlson Sales, Inc., 728 A.2d 534, 540-43 (Conn. Super. Ct. 1998); Turner v. Int'l Harvester Co., 336 A.2d 62, 68-73 (N.J. Super. Ct. Law Div. 1975); Frey v. Harley Davidson Motor Co., 734 A.2d 1, 16-19 (Pa. Super. Ct. 1999); Thompson v. Rockford Mach. Tool Co., 744 P.2d 357, 364-66 (Wash. Ct. App. 1987); Nelson v. Nelson Hardware, Inc., 467 N.W.2d 518, 521-25 (Wis. 1991).

129. 336 A.2d at 72. Turner involved a plaintiff whose husband had purchased a tractor in "asis” condition. Id. at 65 . The plaintiff sued in strict liability, alleging that the tractor was defectively manufactured because the tractor collapsed onto her husband and killed him. Id. at 66. The court held that even though the plaintiff's husband had purchased the tractor "as-is," the used-product seller could be found strictly liable for the husband's death. Id. at 72 .
}

130. Id. at 69 . 
new-product sellers. ${ }^{131}$ This would justify the reasonable consumer standards of "safety, quality[,] and durability" of used products. ${ }^{132}$ The Turner court explained that although other courts had suggested that consumers who purchase used products will have lower expectations of quality and durability,

safety of the general public demands that when a used motor vehicle, for example, is sold for use as a serviceable motor vehicle (and not as junk parts), absent special circumstances, the seller be responsible for safety defects whether known or unknown at time of sale, present while the machine was under his control. ${ }^{133}$

If courts were to hold otherwise, then consumers, along with the public, "bear[] the enterprise liability stemming from introduction of the dangerously defective used vehicle onto the public highways." ${ }^{34}$ The court concluded with the firm statement that "[p]ublic policy demands that the buyer receive a used chattel safe for the purpose intended." 135 The court further opined that "if a buyer wishes to contract away his right to protection, an unequivocal waiver of safety defects must be shown." ${ }^{\text {136 }}$ The Turner court reached an ill-founded conclusion because it failed to consider the fact that the used-product seller will likely have difficulty passing the costs to the original manufacturer.

Other courts have held used-product sellers strictly liable for product defects to deter companies from manufacturing dangerous products. The Arizona Court of Appeals, in Jordan v. Sunnyslope Appliance Propane \& Plumbing Supplies Co., reasoned that most used-product sellers could likely obtain indemnification from manufacturers of defective products, so strict liability was appropriate. ${ }^{137}$ In Jordan, the plaintiff purchased a used propane tank from the defendant. ${ }^{138}$ "The tank was sold without any guarantees or representations regarding its condition." "139 While the defendant's serviceman filled the tank with propane, the hose disconnected, which caused the tank to explode and ultimately destroyed

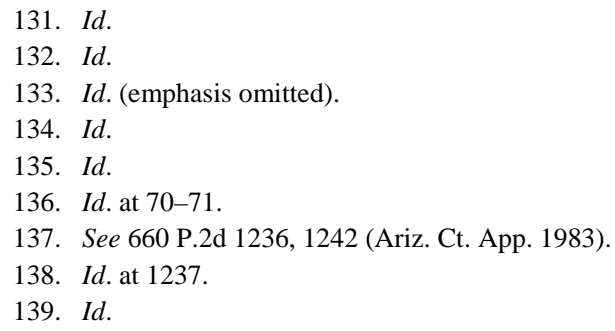


the plaintiff's house. ${ }^{140}$ The court held that strict liability applied to the dealer of the used propane tank because the dealer, just like a newproduct dealer, profits from his business. ${ }^{141}$ Thus, the seller had a responsibility to maintain and to inspect the used tanks before selling them to innocent consumers. ${ }^{142}$ This holding, however, was based largely on section 402A of the Second Restatement. ${ }^{143}$ The court explained that, because section 402A does not distinguish between newand used-product sellers, it applies to all sellers of defective products. ${ }^{144}$ Its argument that subjecting used-product sellers to strict liability deters accidents is weak because a threat of liability cannot deter unknown risks. The Jordan court reached the wrong conclusion. Recently, the Kansas Supreme Court reached the same wrong conclusion.

3. Kansas Adopts the Minority View: Used-Product Sellers Are Subject to Strict Liability After Gaumer v. Rossville Truck \& Tractor Co.

The Kansas Supreme Court recently decided a case involving a plaintiff who sued a used-product seller in strict liability. ${ }^{145}$ The case, Gaumer v. Rossville Truck \& Tractor Co., involved a product liability action alleging negligence and strict liability for injuries to the buyer's son caused by a used hay baler. ${ }^{146}$ The buyer purchased the used baler in "as is" condition, ${ }^{147}$ and the machine was missing a safety shield that would have been included when it was originally manufactured and sold. ${ }^{148}$ Because the baler was more than twenty years old, Rossville Truck \& Tractor Company sold it for only $\$ 1,700{ }^{149}$ A new baler will generally cost in excess of $\$ 60,000{ }^{150}$ One week after the purchase, the baler malfunctioned and injured Gaumer's arm. ${ }^{151}$ After suffering partial amputation of his arm, Gaumer claimed that the seller faced strict liability for selling a defective product in an unreasonably dangerous

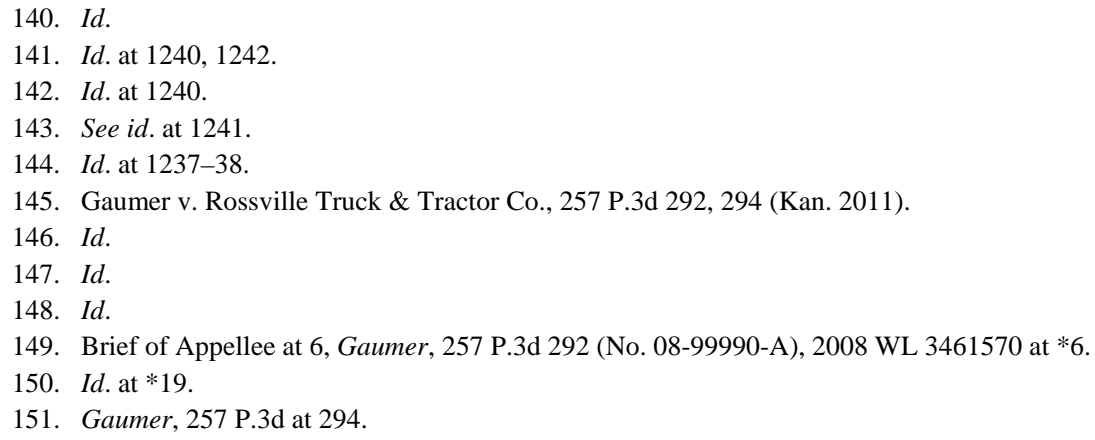


condition. ${ }^{152}$ The court held that Kansas law supports a strict liability claim against a seller of used goods. ${ }^{153}$

The court in Gaumer supported its holding with three main arguments. First, the legislature, in drafting the Kansas Product Liability Act (KPLA), chose to eliminate the language that would have excluded sellers of used goods from the definition of "product sellers."154 Additionally, the legislature included in the definition of "seller" those engaged in the business of selling products "whether the sale is for resale, or for use or consumption." 155 The court construed this legislative intent to support its holding. Second, the court had previously used Brooks v. Dietz to adopt section 402A of the Second Restatement, ${ }^{156}$ which does not distinguish between new and used products. ${ }^{157}$ Third, the court explained that allowing strict liability claims against used-product sellers would further the policy justifications that support the imposition of strict liability. ${ }^{158}$

The court began its analysis with the KPLA, which states that a

“[p]roduct liability claim” ... includes, but is not limited to, any action previously based on: strict liability in tort, negligence; breach of express or implied warranty; breach of, or failure to, discharge a duty to warn or instruct, whether negligent or innocent; misrepresentation, concealment, or nondisclosure, whether negligent or innocent; or under any other substantive legal theory. ${ }^{159}$

The court explained that the KPLA's definition of a "product liability claim"-without additional language to describe its interplay with product liability common law in Kansas-was ambiguous and therefore required an analysis of the KPLA's legislative history. ${ }^{160}$ The court compared the KPLA to the Modern Uniform Product Liability Act

152. Id. Gaumer additionally claimed that the seller was negligent by failing to warn about the potentially dangerous condition of the baler without the safety shield and by failing to inspect the baler before the sale to his father. $I d$. The court affirmed summary judgment on this claim. $I d$. at 295, 308.

153. Id. at 308.

154. Id. at 297, 303.

155. Id. at 297 (quoting KAN. STAT. ANN. § 60-3302(a) (2008)).

156. 545 P.2d 1104, 1108 (Kan. 1976).

157. RESTATEMENT (SECOND) OF TORTS § 402A (1965); see also Gaumer, 257 P.3d at 300.

158. Gaumer, 257 P.3d at 304-05.

159. Id. at 295 (alterations in original) (quoting KAN. STAT. ANN. § 60-3302) (internal quotation marks omitted).

160. Id. at 295-96. 
(MUPLA) and found that the KPLA is essentially a less detailed version of the MUPLA. ${ }^{161}$ The KPLA, however, excluded used-product sellers from the definition of "product sellers" in its final amendment. ${ }^{162}$ Therefore, the court concluded that it must rely on Kansas's common law to determine whether a used-product seller should face strict liability. ${ }^{163}$ The court also noted that two prior cases had relied on Kansas common law to supplement questions in products liability cases when the KPLA was "less than enlightening." 164 Additionally, other states with product liability statutes like the KPLA had "employ[ed] a blended approach" and combined the "application of statutory and common law."165

The court explained that Kansas has followed the doctrine of strict liability as it was set out in section 402A of the Second Restatement. ${ }^{166}$ The court noted as significant that section 402A does not distinguish between sellers of new and used products. ${ }^{167}$ The court then looked to Kansas case law that has addressed strict liability claims. The Kansas Supreme Court first adopted section 402A in Brooks v. Dietz and found that a court could hold a furnace manufacturer strictly liable for injuries that a repairman sustained when a furnace exploded based on the fact that the court considered the furnace a "dangerously defective product." 168 In Kennedy v. City of Sawyer, the Kansas Supreme Court explained two purposes of strict liability. ${ }^{169}$ The first was to "achieve maximum protection for the injured party." ${ }^{\text {"70 }}$ The second was to discourage the marketing of defective products that are a "menace to the public." "71 The Kennedy court also explained that strict liability extends only to the manufacturer and those in the "chain of distribution" of a product. ${ }^{172}$ It includes only those claims by "individuals to whom injury from a defective product may reasonably be foreseen" and applies only when the injured person was using the product for its intended

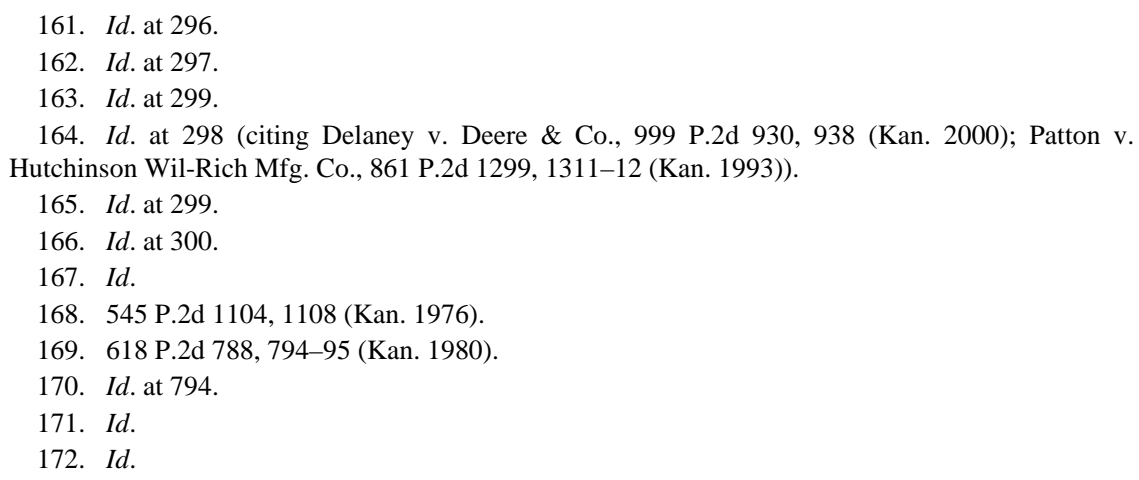


purpose. ${ }^{173}$ The Gaumer court also noted that in Kennedy the Kansas Supreme Court had not distinguished between sellers of new and used products. $^{174}$

The court further supported its decision by examining various policy arguments relating to the imposition of strict liability on used-product sellers. ${ }^{175}$ In addition to two of the policy considerations discussed previously_a desire to achieve maximum protection for the injured party and the promotion of "the public interest in discouraging the marketing of products that have defects that are a menace to the public" "176 - the court noted that Kansas has recognized a third policy justification: protecting consumer expectations. ${ }^{177}$ The Kansas Supreme Court, in Lester v. Magic Chef, Inc., approved the "consumer expectations" test for when a product qualifies as defective. ${ }^{178}$ Comment i to section 402A outlines the consumer expectations test and states in part:

The rule stated in this Section applies only where the defective condition of the product makes it unreasonably dangerous to the user or consumer.... The article sold must be dangerous to an extent beyond that which would be contemplated by the ordinary consumer who purchases it, with the ordinary knowledge common to the community as to its characteristics. ${ }^{179}$

The consumer expectations test ${ }^{180}$ is the formal test for defectiveness in Kansas. After considering these policy reasons, the Gaumer court explained that they favor extending strict liability to sellers of used goods. ${ }^{181}$

Gaumer recognized that a Kansas federal court predicted in Sell $v$. Bertsch \& Co. that Kansas would not impose strict liability on sellers of used goods. ${ }^{182}$ Regardless, the Gaumer court asserted that the federal court's interpretation of strict liability law and used-product sellers

\footnotetext{
173. Id. (gathering cases). For further explanation of the "chain of distribution" liability theory, see Wilcheck v. Doonan Truck \& Equip., Inc., 552 P.2d 938, 942-43 (Kan. 1976).

174. Gaumer v. Rossville Truck \& Tractor Co., 257 P.3d 292, 300 (Kan. 2011).

175. Id. at 303-05.

176. Id. (quoting Kennedy, 618 P.2d at 794); see also supra Part II.C.1-2.

177. Gaumer, 257 P.3d at 300, 303.

178. 641 P.2d 353, 361 (Kan. 1982).

179. RESTATEMENT (SECOND) OF TORTS § 402A cmt. i (1965).

180. See supra Part II.C.3.

181. 257 P.3d at 303-04.

182. Id. (citing Sell v. Bertsch \& Co., 577 F. Supp. 1393, 1399 (D. Kan. 1984)).
} 
"ignores our precedent and fails to acknowledge the elements we set forth for a strict liability claim." 183 Moreover, Sell did not consider the defenses available to used-product sellers in Kansas to defend against strict liability claims. ${ }^{184}$ This presumably would have changed the Sell court's holding because it based its decision on the fact that a usedproduct seller is outside the chain of distribution and, therefore, the purpose of strict liability to "discourage[] the marketing of defective products," would not be furthered by extending strict liability to usedproduct sellers. ${ }^{185}$ Ultimately, the Gaumer court found that there was no convincing argument against allowing strict liability claims against usedproduct sellers in Kansas. ${ }^{186}$

Lastly, the court addressed the policy considerations that Rossville Truck \& Tractor had asserted against extending strict liability to usedproduct sellers. ${ }^{187}$ The first was that strict liability would increase the cost of used goods, and the second was that these increased costs would drive used-product sellers out of business. ${ }^{188}$ The Kansas Supreme Court dismissed these arguments by pointing to the KPLA defense provided by Section 60-3306 of the Kansas Statutes. ${ }^{189}$ This defense, the court reasoned, "will often be well-suited for a defendant such as Rossville Truck \& Tractor, a used-products seller of farm equipment that may not know the history of an item and has no duty to inspect for defects." ${ }^{190}$ In conclusion, the court found that, although there are strong policy

183. Id.

184. Id.; see also KAN. STAT. ANN. § 60-3306 (2005).

"A product seller shall not be subject to liability in a product liability claim arising from an alleged defect in a product, if the product seller establishes that:

(a) [s]uch seller had no knowledge of the defect;

(b) such seller in the performance of any duties the seller performed, or was required to perform, could not have discovered the defect while exercising reasonable care;

(c) the seller was not a manufacturer of the defective product or product component;

(d) the manufacturer of the defective product or product component is subject to service of process either under the laws of the state of Kansas or the domicile of the person making the product liability claim; and

(e) any judgment against the manufacturer obtained by the person making the product liability claim would be reasonably certain of being satisfied."

Id.

185. Sell, 577 F. Supp. at 1399 (citing Kennedy v. City of Sawyer, 618 P.2d 788, 794 (Kan. 1980)).

186. Gaumer, 257 P.3d at 303.

187. Id. at 304 .

188. Id.

189. Id.

190. Id. 
implications for both sides, the legislature's deliberate removal of language from the KPLA that would have differentiated between sellers of new and used products left the court "reluctant to deviate from its selected path.”191

\section{ANALYSIS}

The Kansas Supreme Court's decision in Gaumer was misguided. Exposing all used-product sellers to strict liability under all circumstances is inappropriate because policy considerations do not support this conclusion. Instead, courts should follow the approach outlined in the Third Restatement, which provides a better method for determining when to allow strict liability claims against used-product sellers. The court in Gaumer failed to consider the Third Restatement approach and misinterpreted Kansas legal precedent. Gaumer should have been a negligence case, not a strict liability case. Additionally, three of the policy considerations that have conventionally supported strict liability-enterprise liability, deterrence of risks associated with placing defective products into the stream of commerce, and implied representation of product safety-do not support imposing strict liability on all product sellers.

This section first analyzes the reasoning and holding of Gaumer. It then argues that courts should adopt the Third Restatement, as it provides a compromise for courts to follow in determining when to allow strict liability claims against used-product sellers. Then, it examines the policy justifications supporting strict liability and concludes that these do not support imposing strict liability on used-product sellers.

\section{A. An Analysis of the Kansas Supreme Court's Reasoning in Gaumer}

The court in Gaumer found it significant that the legislature, in drafting the KPLA, eliminated language that would have excluded sellers of used goods from the definition of "product sellers" 192 and that section 402A does not distinguish between sellers of new and used products. ${ }^{193}$ The court should not have focused on the Second Restatement, but rather it should have considered section 8 of the Third Restatement. Section 8,

191. Id. at 304-05.

192. Id. at 303.

193. Id. 
which superseded section 402A in 1998, synthesizes all of the changes in products liability law that have occurred since the publication of section 402A. ${ }^{194}$ Although Kansas courts have rarely addressed the Third Restatement, ${ }^{195}$ the Kansas Supreme Court should look to the updated Restatement because it specifically addresses sales of used goods. Therefore, it is insignificant that neither section 402A nor the KPLA distinguishes between sellers of new and used goods.

The Gaumer court also addressed prior Kansas cases that had outlined three purposes of strict liability-to protect injured parties, to discourage marketing of defective products, ${ }^{196}$ and to protect consumer expectations. ${ }^{197}$ These policies all generally support the doctrine of strict liability. They are also furthered by the Third Restatement, which protects consumer expectations by imposing strict liability on sellers who sell a product in "like new" condition or a product that has been remanufactured so that a consumer can justifiably rely on it to be in safe, working order. ${ }^{198}$ The court purported to apply the "consumer expectations" test in Gaumer. ${ }^{199}$ This requires that the product sold be more dangerous than an ordinary consumer with common knowledge would have contemplated when he bought it. ${ }^{200}$ The baler at issue in Gaumer, however, simply lacked a safety shield. ${ }^{201}$ It was not technically defective because its lacking a safety shield should have been obvious to the purchaser. Gaumer should have been a simple negligence case. If the court had wanted to ensure that used-product dealers do not sell products that are missing an important piece, such as the safety shield in this case, it should have applied the negligence standard to the case. There was no need to allow a strict liability claim against Rossville Truck \& Tractor. Section 8 of the Third Restatement would have protected Gaumer because it allows a negligence claim against a party who fails to exercise reasonable care by creating a defect or allowing a defect to remain when reasonable care would have eliminated it. ${ }^{202}$

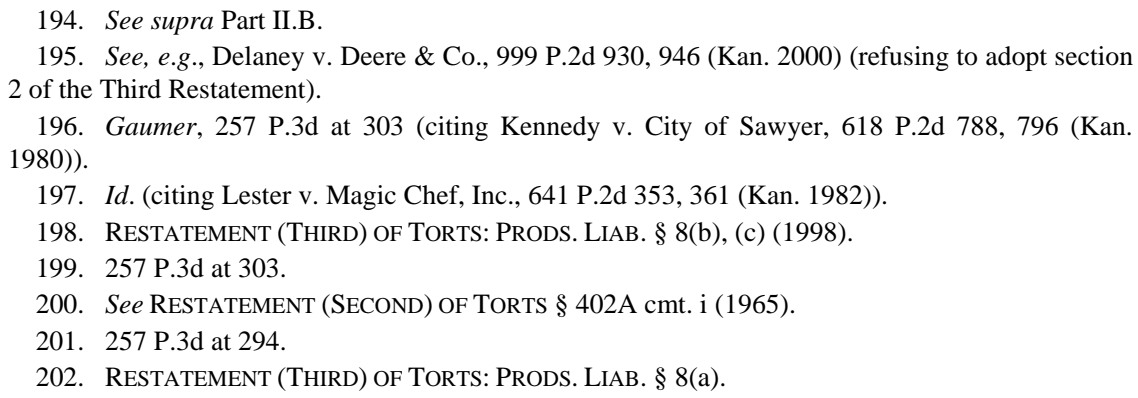


The Gaumer court also looked to Brooks, ${ }^{203}$ a prior case in which the Kansas Supreme Court had allowed a strict liability claim for a defective furnace that had exploded. ${ }^{204}$ It also relied on Kennedy and noted that it had not distinguished between new and used products. ${ }^{205}$ Neither case, however, provides help for the court in Gaumer. Brooks is irrelevant because, as discussed above, the court should not have considered the baler to be a dangerously defective product. Although it lacked a safety shield, this fact does not automatically make it "defective." Kennedy is also irrelevant because that court's failure to distinguish between new and used products does not imply any intent on behalf of the Kansas Supreme Court-whether the product in Kennedy was new or used was not at issue in the case. ${ }^{206}$ Therefore, it is not significant that the court did not distinguish between the two.

The Gaumer court also referenced the Sell court's prediction that Kansas would not impose strict liability on sellers of used goods. ${ }^{207}$ The Gaumer court, however, stated that the federal court's interpretation of strict liability law and used-product sellers "ignores our precedent and fails to acknowledge the elements we set forth for a strict liability claim.”208 This argument does not make sense, however, because the court cites Mays v. Ciba-Geigy Corp., a case in which the Kansas Supreme Court simply outlines the elements required for a strict liability claim. ${ }^{209}$ Mays is not controlling precedent for the issue of strict liability set forth in Gaumer.

The court also opined that Rossville Truck \& Tractor could take advantage of the KPLA defense outlined in section 60-3306 of the Kansas Statutes. ${ }^{210}$ This defense allows a seller to escape liability when it did not manufacture the defective product. ${ }^{211}$ This defense, however, would not protect a seller like Rossville Truck \& Tractor for two reasons. First, sellers of products where there is a significant period of time between the original sale and the sale of the used product will likely be

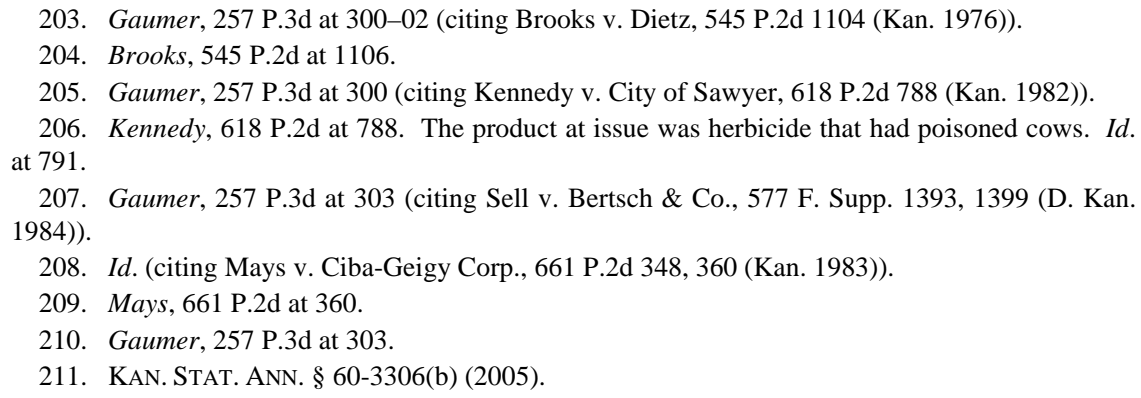


unable to pass the costs of injuries up the chain of distribution to the original manufacturer. Second, the defect in Gaumer came into existence after the baler left the original manufacturer's possession-it was a prior owner presumably removed it at some point. ${ }^{212}$ Therefore, the court inaccurately concluded that this defense would be ideal for sellers like Rossville Truck \& Tractor.

In sum, the Gaumer court's conclusion that there was not a convincing argument against allowing strict liability claims against secondhand sellers in Kansas was ill-founded and based on arguments that do not support its conclusion.

\section{B. Courts Should Adopt Section 8 of the Restatement (Third) of Torts: Products Liability}

Most jurisdictions have adopted the doctrine of strict liability and have followed the version outlined in the Second Restatement. ${ }^{213}$ Section 402A, however, does not directly address the applicability of strict liability to used-product sellers. The ALI published it in 1964, and many unique problems have arisen in products liability law in the last four decades.

In 1998, the ALI published the Third Restatement with the intention of revising and updating the Second Restatement. ${ }^{214}$ The Third Restatement directly addresses liability of sellers or distributors of defective used products ${ }^{215}$ and was meant to essentially supersede the Second Restatement and provide a comprehensive "reformulation and expansion of [section] 402A" and of products liability law generally. ${ }^{216}$ The ALI wrote the Third Restatement to respond to products liability questions "that have become points of serious contention in the courts but were not part of the products liability landscape when the earlier provision was adopted in 1964."217

The Third Restatement is a synthesis of all the case law that has developed since $1964^{218}$ and is meant to provide practitioners with new

\footnotetext{
212. See Brief of Appellee, supra note 149 , at *6.

213. OWEN, supra note 1 , § 5.3 .

214. Publications Catalog, AM. LAW INST., http://www.ali.org/index.cfm?fuseaction= publications.ppage\&node_id=54 (last visited Apr. 15, 2012).

215. Restatement (THIRD) OF TORTS: PRODS. Liab. § 8 (1998).

216. Publications Catalog, supra note 214.

217. Id.

218. RESTATEMENT (THIRD) OF TORTS: PRODS. LIAB. § 8 reporters’ note, summary.
} 
information and guidance that will allow them to analyze complex products liability issues with greater sophistication. ${ }^{219}$ It essentially "limits recovery from a seller of a defective product who resells the product without making any substantial change to it or any representation as to its quality to negligence standards."220 Section 8 allows strict liability claims when a seller represents a product as being "like new" or when the seller has reconditioned, remanufactured, or repaired the product. $^{221}$ It is appropriate for consumers to hold manufacturers and sellers strictly liable under these circumstances because consumers who purchase products that have been reconditioned or are in "like new" condition will have higher expectations concerning the quality and safety of that product.

The first provision, subsection (a), provides a negligence standard and allows a person injured by a used product to bring a negligence claim if he can show that the seller failed to exercise reasonable care by creating a defect or allowing a defect to remain when reasonable care would have eliminated it. ${ }^{222}$ The standard outlined in the first provision provides the fallback standard for injuries caused by a defective product. Used-product sellers are properly subject to liability claims when their negligence causes harm to a buyer. ${ }^{223}$ Consumers' expectations of quality and safety are much lower for used products than they are for new products. ${ }^{24}$ Regardless, buyers still have a right to expect that a used-product seller will exercise reasonable care in distributing a product. $^{225}$ This provision should have governed Gaumer. If it had, Rossville Truck \& Tractor would have had to prove that it had acted reasonably in selling the baler without the safety shield and in "as-is" condition.

The second provision, subsection (b), provides a strict liability standard and allows a person injured by a used product to hold a party strictly liable if the product that caused the injury had a manufacturing defect and the seller marketed the product in a way that would cause a reasonable consumer to believe that the product was in "like new"

\footnotetext{
219. Publications Catalog, supra note 214.

220. Frey v. Harley Davidson Motor Co., 734 A.2d 1, 20 (Pa. Super. Ct. 1999).

221. RESTATEMENT (THIRD) OF TORTS: PRODS. LiAB. § 8(b), (c).

222. Id. § 8(a) \& cmts. b \& e.

223. Id. § $8 \mathrm{cmt}$. b.

224. See discussion infra Part III.C.4.

225. Restatement (ThiRd) OF TORTS: PRODS. Liab. § $8 \mathrm{cmt}$. b.
} 
condition. ${ }^{226}$ In Gaumer, however, there was no manufacturing defectat some point within the twenty-one-year period between the time the baler was manufactured and resold, the safety shield was removed. Additionally, Rossville Truck \& Tractor did not market the baler in a way that would lead a reasonable consumer to believe that it was in "like new" condition because it was obviously lacking the safety shield and was sold "as-is."

The third provision, subsection (c), also provides a strict liability standard and allows a consumer to bring a claim against a seller who has remanufactured a product that has a defect that ultimately injures a consumer. ${ }^{227}$ The defects under subsection (c) "include manufacturing defects, design defects, and defects based on inadequate instructions and warnings."228 This provision means that used-product sellers would incur liability for these types of defects the same way that the seller or manufacturer of a new product would. ${ }^{229}$ This, however, would not apply in Gaumer because Rossville Truck \& Tractor did nothing to restore or remanufacture the baler.

The last provision, subsection (d), essentially provides that a failure by a manufacturer or seller to comply with a product safety statute or regulation will subject it to liability for injuries caused by the product. ${ }^{230}$ This provision is not applicable in Gaumer, though it might provide for a more effective and efficient approach to the issue of used-product safety. A regulatory body could outline with some precision those safety matters that a used-product seller must satisfy before making a sale. An industry-specific statute or regulation that provides guidance to usedproduct sellers would instruct such sellers as to the required, pre-sale improvements. This approach would make sense for used products that are sold frequently and could have serious safety concerns, such as used cars.

The Third Restatement provides a theory of limited strict liability for used-product manufacturers and sellers, which is a reasonable compromise for courts to adopt and follow. It satisfies consumers' reasonable expectations for used products that they purchase by imposing strict liability under subsections (b) and (c). Courts should

226. Id. § 8(b) \& cmts. b, f \& g.

227. Id. § 8(c).

228. Id. § $8 \mathrm{cmt}$. b.

229. See id. § 8(c) \& cmts. b \& i.

230. Id. § 8(d). 
look to the Third Restatement when analyzing products liability claims against used-product sellers because it provides much needed guidance to help courts determine those circumstances under which used-product sellers should incur strict liability. The Third Restatement limits strict liability across the board because policy considerations that generally support the theory of strict liability do not equally support the conclusion that all secondhand sellers should face strict liability.

\section{Public Policies that Support the Imposition of Strict Liability Against Manufacturers Do Not Similarly Support the Imposition of Strict Liability Against Used-Product Sellers}

\section{Enterprise Liability}

The theory of enterprise liability does not apply to used-product sellers. Some courts have recognized that the theory allows used-product sellers, along with new-product sellers, to distribute their costs of doing business to consumers which will reflect consumer expectations of "safety, quality[,] and durability of used goods."231 This theory works well for manufacturers and sellers of new products. ${ }^{232}$ With new products, the manufacturer may determine the price of the product and add costs to the sales price to pay for future strict liability claims. ${ }^{233}$ Used-product sellers, however, are generally much smaller businesses than manufacturers and new-product sellers, and they cannot easily distribute the costs of doing business to insure against possible injuries that result from their products. New-product manufacturers and sellers, who have the ability to reduce risks that defective products create, must bear the costs to do so. Used-product sellers generally do not have the financial ability to pass on excess costs to consumers to insure against possible injuries because they are in the business of selling used goods at low prices. Such sellers tend to "pitch low prices" to attract buyers who are "looking for the best parlay of quality and low price but are consciously trading off the quality to get the price." ${ }^{\text {,34 }}$ If these sellers were subject to strict liability claims, then they would have to increase the prices of their goods, which in turn could eventually drive them out

\footnotetext{
231. Turner v. Int'l Harvester Co., 336 A.2d 62, 69 (N.J. Super. Ct. Law Div. 1975).

232. Harber v. Altec Indus., Inc., 812 F. Supp. 954, 961 (W.D. Mo.), aff'd 5 F.3d 339 (8th Cir. 1993).

233. Id.

234. LaRosa v. Superior Court, 176 Cal. Rptr. 224, 233-34 (Ct. App. 1981).
} 
of business. ${ }^{235}$ Used-product sellers are also not in the best position to pass costs back to the original manufacturer-it is nearly impossible for the seller to establish that a defect in a product was present when it left the manufacturer's possession.

If used-product sellers were to bear the costs of strict liability claims, then their ability to sell used products at reduced costs would diminish significantly. If used products were priced the same as or close to the same as new products, then no rational consumer would buy the used product over the new one. Imposing strict liability on used-product sellers could, in theory, wipe out the entire secondhand market and, therefore, is not sound policy.

2. Deterrence of Risks Associated with Placing Defective Products into the Stream of Commerce

This policy justification does not support subjecting used-product sellers to strict liability because they are not directly involved in the initial manufacturing, marketing, or distributing process and likely have no relationship with the original seller or manufacturer of a product. ${ }^{236}$ Used-product sellers would have to bear the entire risk and costs of injuries on their own. This justification supports holding manufacturers of new products strictly liable for injuries because the manufacturer has the ability to repair or stop manufacturing a dangerous or defective product. Used-product sellers, on the other hand, do not generally have a "ready channel of communication ... [to] exchange information about possible dangerous defects" with manufacturers or distributors. ${ }^{237}$ Usedproduct sellers cannot always easily locate the original seller or manufacturer or, for older products, cannot identify the original manufacturer or seller. They also face problems with manufacturers and sellers that go out of business or with indemnity claims falling outside of state statutes of limitation. ${ }^{238}$ Used-product sellers would have to overcome all of these hurdles to recover compensation from the original manufacturer or seller if the used-product seller incurred strict liability.

235. Id.

236. Id. at 231.

237. Tillman v. Vance Equip. Co., 596 P.2d 1299, 1304 (Or. 1979).

238. Id. (stating that problems used-product sellers face with claims for indemnity include "statutes of limitation and the increasing difficulty as time passes of locating a still existing and solvent manufacturer"). 
Additionally, if used-product sellers were responsible for inspecting products for defects and insuring against all defects irrespective of their ability to discover them, then they "would in effect become an insurer against defects [that] had come into existence after the chain of distribution was completed, and while the product was under the control of one or more consumers." ${ }^{239}$ For example, in a case involving an axle shift that had weakened from heat exposure and eventually failed, an injured consumer sued a salvage dealer claiming strict liability. ${ }^{240}$ The dealer had not disassembled or inspected the axle prior to selling it, and the court held that the dealer would have had no way to discover this defect because it "could only have been discovered by a skilled metallurgist." ${ }^{241}$ For cases such as this, imposing an obligation on usedproduct sellers would be far too burdensome and costly for them to handle. It is unrealistic to expect used-product sellers to have the ability or resources to perform extensive inspections of all of their products. It is rare for used-product sellers to have "anything comparable to a factory reconditioning process" 242 because they generally tend to sell a small number of many different types of products.

The justification of risk deterrence ultimately does not support strict liability for used-product sellers because it would not achieve the goal of reducing the risk of dangerous products being put into the stream of commerce. Rather, it would likely lead to increased costs of used goods.

\section{Implied Representation of Product Safety}

Manufacturers who make products and place them into the stream of commerce "impliedly represent their goods as safe for intended use."243 This policy justification protects consumer beliefs that the products they purchase are safe for use. ${ }^{244}$ When someone buys a new product, he assumes that the product is safe for use. When someone buys a used product in "as is" condition or without any guarantee of the product's

239. Peterson v. Lou Bachrodt Chevrolet Co., 329 N.E.2d 785, 787 (Ill. 1975) (citing RESTATEMENT (SECOND) OF TORTS § 402A cmt. f (1965)).

240. Grimes v. Axtell Ford Lincoln-Mercury, 403 N.W.2d 781, 781-82 (Iowa 1987).

241. Id. at 782, 785. The court refused to extend strict liability to the used-product seller for latent defects that arose while the goods were in the possession of the previous owner. Id. at 785.

242. LaRosa v. Superior Court, 176 Cal. Rptr. 224, 234 (Ct. App. 1981).

243. Thompson v. Rockford Mach. Tool Co., 744 P.2d 357, 361 (Wash. Ct. App. 1987) (quoting Hall v. Armstrong Cork, Inc., 692 P.2d 787, 791 (Wash. 1984) (en banc)).

244. See Humes, supra note 98, at 395. 
quality, there is no similar implied representation by the seller that the product is safe for use. Consumers pay much less for used products because they understand that these products may not last as long as or work as well as new ones. ${ }^{245}$ This policy justifies subjecting newproduct manufacturers and sellers to strict liability claims because it forces them to guarantee the safety of their products. It does not, however, support the argument that used-product sellers should inspect and repair their products before selling them, as it would be very costly and consumers who purchase secondhand goods do not have the same kinds of expectations in terms of quality or safety of those products. ${ }^{246}$ Further, consumers who purchase new goods expect that the product they buy, which is likely priced higher than a comparable used product, will be safe and of good quality. The cheaper price of a used product should lower a consumer's expectations of quality. Therefore, a buyer who chooses to purchase a used product generally should have much lower expectations than a buyer who chooses to purchase a similar new product.

The used-product market is vastly different from the new-product market because it "operate[s] on the apparent understanding that the seller ... makes no particular representation about [a product's] quality by simply offering [it] for sale."247 Therefore, when a consumer purchases a used product, he should not expect that it is in good condition or that it is working properly. The used-product market gives sellers and consumers a great amount of flexibility in terms of pricing and representations of quality. ${ }^{248}$ If a consumer wanted to assure that the purchased product was of good quality, then he could ask the seller to make a guarantee of quality or a warranty to that effect. ${ }^{249}$ If a usedproduct seller guarantees the quality or safety of a product, then imposing strict liability on that seller if the product injures a consumer

245. Harber v. Altec Indus., Inc., 812 F. Supp. 954, 964 (W.D. Mo.), aff'd, 5 F.3d 339 (8th Cir. 1993).

246. See Tillman v. Vance Equip. Co., 596 P.2d 1299, 1303-04 (Or. 1979); see also Turner v. Int'l Harvester Co., 336 A.2d 62, 69 (N.J. Super. Ct. Law Div. 1975) (consumer expectations of "safety, quality[,] and durability of used goods" are not the same for used goods as they are for new goods).

247. Tillman, 596 P.2d at 1303.

248. Wilkinson v. Hicks, 179 Cal. Rptr. 5, 8 (Ct. App. 1981).

249. See Tillman, 596 P.2d at 1303-04 (stating that "[i]f a buyer wants some assurance of quality, he typically either bargains for it in the specific transaction or seeks out a dealer who routinely offers it”); see also Wilkinson, 179 Cal. Rptr. at 8. 
would adequately protect reasonable consumer expectations. ${ }^{250}$ In all other circumstances, such as when a product is sold in "as is" condition without any representation of quality or safety, strict liability is inappropriate because consumers could not reasonably expect that the product is safe for use. In Gaumer, the price of the baler and the fact that it was sold in "as is" condition made it clear to Gaumer that Rossville Truck \& Tractor did not imply that the baler was safe for use. It is unlikely that any reasonable consumer would assume that Rossville Truck \& Tractor impliedly represented that a baler that was originally sold twenty-one years ago was safe. As more time passes between the original sale and the resale, an inference of safety should continually weaken and eventually disappear.

\section{Consumer Compensation}

Consumers injured by defective products are "powerless to protect themselves"251 and should not have to bear the costs associated with injuries caused by a defective product. This policy justification supports holding both new- and used-product sellers strictly liable for injuries caused by their products because innocent victims should receive compensation for their injuries. If manufacturers did not face strict liability for selling defective products, then victims would not receive compensation and manufacturers would unfairly profit from selling defective products to consumers without being held accountable or facing any ramifications.

The consumer compensation justification has been particularly important because of a recent increase in used-product sales. ${ }^{252}$ Sales at pawnshops, antique stores, and other secondhand shops grew twice as fast as other retailers, ${ }^{253}$ presumably those that sell brand-new products. The rise of eBay and the economic slowdown has seen [secondhand] goods reach new heights of popularity." 254 Since the financial crisis of

250. Strict liability has been imposed on sellers under similar circumstances. See, e.g., Crandell v. Larkin \& Jones Appliance Co., 334 N.W.2d 31, 32, 35-36 (S.D. 1983) (imposing strict liability on seller of a dryer that was "[g]uaranteed" to be a "[q]uality [r]econditioned [u]nit" (internal quotation marks omitted)).

251. Greenman v. Yuba Power Prods., Inc., 377 P.2d 897, 901 (Cal. 1963) (en banc).

252. Leslie Kaufman, They Can Get It for You Resale; Secondhand Stores Moving into the Retail Mainstream, N.Y. TIMES, Apr. 26, 2000, at C1 (noting that in 1997 "Americans spent some \$12 billion on merchandise bought at these secondhand stores, about a 30 percent jump from 1992”).

253. Id.

254. Louise Jack, From Rags to Riches, MARKETING WK. (Sept. 3, 2009), 
2008, however, consumers have been spending less and less money. The downturn of the U.S. economy has led consumers to spend less money on new goods and search out deals from used-product dealers, such as consignment shops, thrift stores, garage sales, and online used-good retailers. ${ }^{255}$ Consumers who suffer from product-related injuries are often unable to afford the consequences of those injuries, such as the overwhelming costs associated with health and medical bills and loss of time. ${ }^{256}$ Because of this, one may argue that consumers need protection regardless of the fact that they chose to purchase a used product rather than a new one.

When a person purchases a used product, however, the general rule is caveat emptor - the buyer of used goods essentially must be "willing to take his or her chances in exchange for a cheaper price." ${ }^{257}$ Therefore, although this policy justification supports subjecting used-product sellers to strict liability, it is not, by itself, sufficient to impose liability on these sellers because the costs that they would incur from paying consumers for injuries would eventually drive them out of business and would ultimately do nothing to reduce the risks associated with defective products being placed into the stream of commerce. ${ }^{258}$

\section{CONCLUSION}

The Kansas Supreme Court's decision in Gaumer v. Rossville Truck \& Tractor Co., allowing a strict liability action against the seller of a used product, ${ }^{259}$ was misguided. Exposing used-product sellers to strict liability claims under all circumstances is inappropriate because the policy considerations that have traditionally supported strict liability do not similarly support imposing strict liability on secondhand dealers and used-product sellers. Instead, the Gaumer court should have followed section 8 of the Third Restatement, which outlines a more comprehensive and logical approach for courts to use in deciding when

\footnotetext{
http://www.marketingweek.co.uk/from-rags-to-riches/3003993.article.

255. See Sandra Block \& Barbara Hagenbaugh, Downturn Has More Folks Stashing Their Cash, USA TODAY, Dec. 1, 2008, at B1.

256. Escola v. Coca Cola Bottling Co., 150 P.2d 436, 441 (Cal. 1944) (en banc) (Traynor, J., concurring).

257. Harber v. Altec Indus., Inc., 812 F. Supp. 954, 964 (W.D. Mo.), aff'd 5 F.3d 339 (8th Cir. 1993).

258. See supra Part III.C.2.

259. Gaumer v. Rossville Truck \& Tractor Co., 257 P.3d 292, 308 (Kan. 2011).
} 
to subject used-product sellers to strict liability. It provides a compromise and allows strict liability claims when they are justified under the circumstances, but it includes a negligence provision that applies when strict liability is inappropriate. Under section 8, Gaumer should have been a simple negligence case. If the Gaumer court wanted to ensure that used-product sellers do not sell products that are missing an important piece or that are not safe for use, then it should have applied the negligence standard. This way, Rossville Truck \& Tractor would have had the opportunity to establish that it had acted reasonably in selling the baler in "as is" condition without the safety shield rather than immediately facing strict liability.

Additionally, the policy justifications behind strict liability do not support its imposition on used-product sellers across the board. These sellers are not directly involved with the initial distribution process for products and generally have no direct relationship with the original manufacturer and no way to influence the manufacturer to produce safer products. And if used-product sellers were required to inspect and repair all of their used products, then they would be forced to increase the prices of their products. This, in turn, would frustrate the purpose of the secondhand market. Therefore, it is appropriate for courts to follow section 8 of the Third Restatement and allow only a limited theory of strict liability for used-product sellers. 